\title{
OPTIMALISASI PENGGUNAAN APLIKASI CLOUD COMPUTING SEBAGAI SARANA PENGELOLAAN KUESIONER BAGI GURU MUHAMMADIYAH TANON
}

\author{
${ }^{1}$ Sukirman, Muhammad Miftakhul Rohadi Putra, Astriana Jihan Kusumawati \\ Pendidikan Teknik Informatika, Fakultas Keguruan dan Ilmu Pendidikan \\ Universitas Muhammadiyah Surakarta \\ email: 1'sukirman@ums.ac.id
}

\begin{abstract}
Abstrak
Aplikasi cloud computing merupakan aplikasi yang cara penggunaannya membutuhkan jaringan internet. Salah satu keunggulannya yaitu tidak memerlukan media penyimpanan namun dapat diakses dari berbagai tempat. Akan tetapi, sebagian besar guru Muhammadiyah di kecamatan Tanon, Sragen, belum memiliki pengetahuan yang lebih jauh tentang aplikasi cloud computing ini, khususnya Google Drive. Padahal aplikasi ini dapat dimanfaatkan untuk berbagai kepentingan akademik maupun nonakademik, misalnya pengelolaan kuesioner. Selama ini proses distribusi kuesioner dan pengolahannya dilakukan secara konvensional menggunakan kertas cetak, digandakan, dikumpulkan kembali dan baru kemudian diolah. Tentu saja hal ini kurang efektif di era teknologi informasi ini. Untuk itu perlu dilakukan workshop pembelajaran tentang cara penggunaan aplikasi berbasis cloud computing bagi para guru tersebut. Metode workshop dilakukan dengan model pembelajaran aktif (active learning) sehingga memungkinkan peserta aktif dalam mengikuti kegiatan. Setelah kegiatan, peserta diwajibkan mengisi kuesioner untuk mengetahui tanggapan terhadap kegiatan. Secara umum, peserta kegiatan menyatakan puas dan kegiatan ini bermanfaat serta bisa ditindaklanjuti untuk kegiatan sejenis di masa mendatang.
\end{abstract}

Kata kunci: cloud computing, google drive, active learning, workshop pembelajaran, tanon

\begin{abstract}
Cloud computing application is an application that the usage requires internet network. One of the advantages is that it does not require storage media, but can be accessed from any places. However, most Muhammadiyah teachers in Tanon sub-district, Sragen, do not have further knowledge about this cloud computing application, especially Google Drive. Though this application can be used for various academic and non-academic interests, for example questionaire management. During this time, the survey distribution process and its processing are carried out conventionally using printed paper, duplicated, collected again, processed and reported. Of course this is less effective in this era of information technology. For this reason, it is necessary to conduct a learning workshop on how to use cloud computing-based applications for these teachers. The workshop method is conducted using an active learning model to enable active participants to participate in activities. After the activity, participants are required to fill out a questionnaire to find out the response to the activity. In general,
\end{abstract}


the activity participants expressed satisfaction and this activity was useful and could be followed up for similar activities in the future.

Keywords: cloud computing, google drive, active learning, learning workshop, tanon

\section{PENDAHULUAN}

Cloud computing merupakan komputasi yang dilakukan dengan memanfaatkan jaringan internet sebagai sumber daya utama dan digunakan oleh banyak pengguna (Fardani et al., 2011). Salah satu teknologi berbasis cloud computing yang mudah ditemui dalam kehidupan sehari-hari misalnya Google Drive, sebuah aplikasi layanan penyimpanan online atau dalam jaringan (daring) yang dimiliki oleh perusahaan raksasa internet Google inc. (Warsito \& Yuliandini, 2017). Selain memberikan layanan penyimpanan, aplikasi ini juga menyediakan aplikasi yang memungkinkan pengguna untuk mengolah dokumen perkantoran maupun presentasi seperti yang dimiliki Microsoft Office, antara lain Google Docs, Sheets, Slides dan bahkan formulir (Handayani et al., 2017) (Iqbal et al., 2018). Perbedaannya, pengguna dapat langsung memakai aplikasi tanpa harus melakukan instalasi di komputer, serta tidak membutuhkan media penyimpanan seperti harddisk atau flashdisk, akan tetapi disimpan di jaringan internet.

Aplikasi Google Drive dapat dipasang dan dibuka melalui smartphone Android maupun langsung di komputer menggunakan aplikasi peramban internet atau browser. Kapasitas penyimpanan yang disediakan cukup besar, yaitu 15 Giga Byte (GB), secara gratis hanya dengan memiliki akun Google (Google, 2018). File yang tersimpan di Google Drive dapat dibagikan secara mudah kepada pengguna lain sehingga memungkinkan untuk dapat membuka berkas dari mana pun, kapan pun, dan oleh siapa pun. Dengan demikian, sebuah berkas dokumen dapat dikerjakan oleh banyak orang dalam waktu yang bersamaan. Karena itulah, pemanfaatan Google Drive ini dapat mempercepat proses pengerjaan secara cepat. Selain itu, penyimpangan di ruang cloud (awan) juga bisa mengurangi penggunaan kertas guna menunjang paperless office (Ningrum et al., 2015). Karena cara kerja Google Drive berbasis cloud computing yang menggunakan jaringan internet sebagai server untuk mengolah data, sementara untuk penyimpanan dilakukan menggunakan virtual internet dan dilanjutkan ke server (Euis \& Heryana, 2018). Jika dilihat dari kemudahan cara aksesnya, syarat utama yang diperlukan adalah jaringan internet, baik menggunakan komputer desktop, laptop, tablet, maupun smartphone.

Berdasarkan hasil observasi dan wawancara yang dilakukan di SMK Muhammadiyah 8 dan SMP Muhammadiyah 5 di kecamatan Tanon, Sragen, sebagian besar guru dan siswa sudah memiliki smartphone yang terhubung internet. Selain itu, di tempat kerjanya juga sudah terdapat komputer yang memiliki jaringan internet. Akan tetapi, sebagian besar belum mengetahui manfaat dan kegunaan teknologi berbasis cloud seperti Google Drive. Sebagai contoh, salah satu aktivitas yang sedikit kurang efektif dan masih menggunakan kertas (non-paperless) yaitu penyebaran kuisioner ke siswa. Padahal, data hasil kuesioner tersebut harus segera diolah dan dilaporkan ke Data Pokok Pendidikan (Dapodik) Nasional. Dengan menggunakan kuisioner berbasis kertas atau biasa disebut dengan metode konvensional, dapat menjadikan kinerja di sekolah dan urusan akademik lainnya kurang efektif, karena harus membuat, menggandakan, dan menyebar kuisioner secara manual menggunakan kertas. Setelah kuesioner tersebar dan kembali dikumpulkan, data tersebut baru disalin dan kemudian diolah menggunakan komputer. Proses seperti ini tentu saja akan memakan waktu dan membutuhkan tenaga lebih banyak.

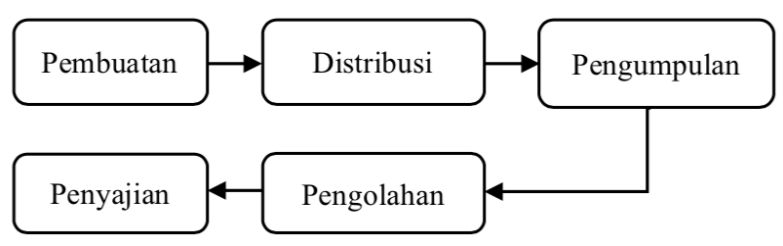

Gambar 1. Alur kuesioner konvensional

Warta LPM, Vol. 22, No. 2, September 2019 
Proses pembuatan dan penyebaran kuesioner serta pengolahan secara konvensional seperti yang disajikan pada gambar 1 ini dapat dilakukan secara lebih efektif jika dilakukan menggunakan aplikasi berbasis cloud seperti Google Form yang terdapat pada Google Drive. Karena aplikasi tersebut sudah terhubung dengan internet sehingga memudahkan proses pembuatan kuesioner, distribusi dan pengolahan secara cepat karena tidak perlu dicetak dan digandakan untuk disebarkan, cukup dibagikan menggunakan perangkat media sosial yang terpasang di smartphone atau email maupun media sosial lain yang terhubung dengan internet. Permasalahannya, para guru Sekolah Muhammadiyah di kecamatan Tanon ini masih belum mengetahui cara pengelolaan kuesioner atau survei melalui aplikasi berbasis cloud computing, sehingga sumber daya yang dimilikinya masih kurang bisa dimanfaatkan secara efektif. Untuk itulah perlu diadakan pelatihan pemanfaatan aplikasi cloud computing Google Drive guna meningkatkan efektifitas kerja di lingkungan sekolah maupun urusan akademik lain di kecamatan Tanon, kabupaten Sragen. Dengan demikian, pemanfaatan sumber daya internet maupun perangkat smartphone yang dimiliki menjadi lebih efektif.

\section{METODE PELAKSANAAN}

Kegiatan ini dilaksanakan dalam beberapa tahap antara lain observasi, wawancara, perumusan masalah, pemberian solusi dan pelaksanaan kegiatan, monitoring, evaluasi, dan penarikan kesimpulan. Secara umum dapat diilustrasikan seperti gambar 2 .

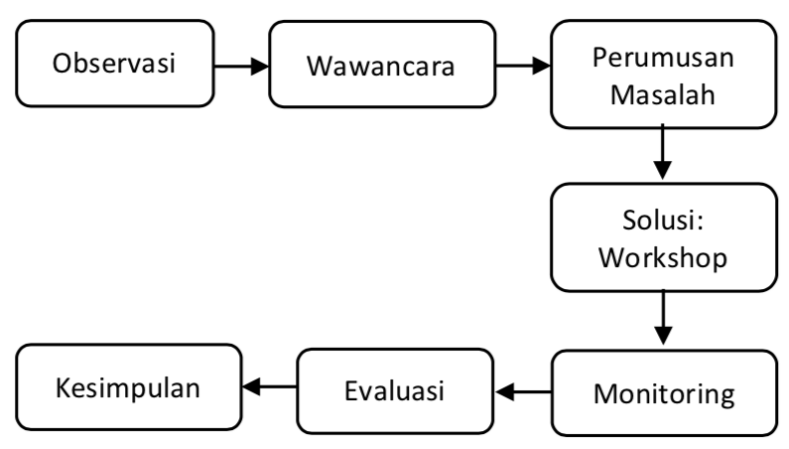

Gambar 2. Metode pelaksanaan kegiatan
Secara lebih detil, metode pelaksanaan kegiatan pengabdian masyarakat ini dapat diuraikan sebagai berikut:

a. Observasi, dilakukan untuk melihat secara langsung kondisi di lapangan sehingga diperoleh gambaran jelas tentang kondisi yang ada. Dengan demikian akan diketahui kelemahan dan potensi yang bisa dikembangkan lebih lanjut.

b. Wawancara, dilakukan untuk mengetahui permasalahan secara lebih mendalam karena melalui pengamatan dari luar saja masih kurang sehingga diperlukan wawancara lebih mendalam terhadap pihak yang mengalami langsung di lapangan.

c. Perumusan masalah, digunakan untuk menyederhanakan masalah yang diperoleh dari observasi dan wawancara sehingga penanganan dan solusi terhadap permasalahan menjadi lebih tepat.

d. Workshop, merupakan salah satu solusiyang ditawarkan berdasarkan permasalahan di lapangan. Workshop dilakukan agar permasalahan dapat teratasi secara lebih baik.

e. Monitoring, digunakan untuk mengetahui sejauh mana hasil workshop yang telah dilaksanakan, sehingga akan terpantau kemajuan dan kekurangannya.

f. Evaluasi dilakukan setelah proses pelaksanaan kegiatan dan monitoring dengan tujuan untuk mengetahui sejauh mana efektifitas kegiatan yang telah dijalankan. Sehingga adakan diperoleh informasi apakah sudah sesuai atau masih perlu perbaikan untuk kegiatan selanjutnya.

g. Kesimpulan, dibuat sebagai hasil akhir dari kegiatan yang telah dilaksanakan. Sehingga diperoleh gambaran umum hasil kegiatan yang telah dilaksanakan.

Sebelum memulai pelaksanaan workshop, peserta diminta untuk mengisi kuesioner awal. Tujuannya untuk mengetahui sejauh mana pemahaman mereka tentang Google Drive dan aplikasinya. Selain itu, kuesioner ini juga digunakan untuk mengetahui seberapa jauh peserta memahami cara penggunaan dan pemanfaatannya. Pengisian kuesioner dilakukan 
secara daring yang dibuat menggunakan aplikasi Google Form dengan pembobotan Skala Likert dengan 5 nilai (Syofian et al., 2015). Nilai 1 menyatakan Sangat Tidak setuju, 2 : Tidak setuju, 3: Ragu-ragu, 4 : Setuju, dan 5: Sangat Setuju. Proses pengisian kuesioner yang dilakukan peserta dilakukan menggunakan komputer dengan cara membuka link yang dibuat oleh Pemateri. Adapun instrumen pertanyaan kuesioner sebelum workshop dilakukan tertulis pada tabel 1.

Tabel 1. Kuesioner sebelum workshop

\begin{tabular}{|c|c|}
\hline No. & Pertanyaan \\
\hline 1. & $\begin{array}{l}\text { Saya sudah mengetahui aplikasi Cloud } \\
\text { Computing Google Drive }\end{array}$ \\
\hline 2. & $\begin{array}{l}\text { Saya sudah terbiasa menggunakan } \\
\text { Google Drive }\end{array}$ \\
\hline 3. & $\begin{array}{l}\text { Saya sudah mengetahui jenis-jenis } \\
\text { aplikasi Google Drive }\end{array}$ \\
\hline 4. & $\begin{array}{l}\text { Saya sudah mengetahui cara } \\
\text { penggunaan aplikasi Google Drive }\end{array}$ \\
\hline
\end{tabular}

Tahap berikutnya yaitu pelaksanaan kegiatan workshop yang dilakukan dalam bentuk penyampaian tutorial dan melakukan praktek secara langsung. Tutorial disampaikan secara oral oleh pemateri dan peserta menjalankan praktek sesuai instruksi yang disampaikan oleh pemateri. Penyampaian materi dilakukan dengan metode pembelajaran aktif (active learning) (Kristin, 2017), sehingga menjadikan suasana workshop menjadi lebih aktif. Apabila terdapat kendala saat proses berlangsung, peserta dapat langsung menanyakan kepada pemateri tanpa harus menunggu sesi materi selesai. Sehingga peserta diminta untuk lebih aktif dalam kegiatan ini.

Kegiatan workshop dilakukan dalam dua waktu yang berbeda dengan jeda satu minggu, yaitu hari di pekan pertama dan hari di pekan kedua. Jeda ini dimaksudkan untuk memberikan kesempatan kepada peserta agar lebih mendalami materi yang sudah disampaikan serta memberikan waktu dalam melakukan eksplorasi fitur (keunggulan) aplikasi yang baru saja diketahui. Hari pertama (pekan 1) disampaikan teori dan pemahaman dasar secara teknis yang disertai dengan praktik langsung tentang cara penggunaan dan pembuatan kuesioner menggunakan aplikasi Google Drive untuk mengelola kuesioner. Sedangkan hari kedua diadakan evaluasi singkat tentang materi yang sudah disampaikan di pekan pertama yang dilanjutkan dengan proses pengolahan data hasil kuesioner beserta proses penyampaian laporan data serta distribusinya. Karena proses distribusi hasil kuesioner bisa disampaikan secara daring maupun offline melalui perangkat pendukung.

Proses workshop ini memerlukan komputer yang terhubung dengan jaringan internet karena aplikasi yang digunakan berbasis internet, sehingga pelaksanaan kegiatan dilaksanakan di laboratorium komputer. Dengan demikian tidak perlu lagi memasang instalasi jaringan internet dan koneksi lainnya. Selain itu, satu komputer juga untuk satu peserta sehingga dapat meningkatkan pemahaman individu peserta dibanding apabila satu komputer untuk dua atau lebih peserta.

Proses monitoring dilakukan selama jeda antara pelaksanaan pekan pertama dan pekan selanjutnya. Dalam monitoring ini peserta dapat berdialog dan berkomunikasi yang dilakukan melalui email, jejaring atau media sosial internet, maupun tatap muka secara langsung. Sehingga diperoleh informasi lebih lengkap tentang kekurangan dan kelemahan peserta guna memberikan solusi terbaik. Sehingga dengan adanya proses monitoring ini peserta lebih terpantau kondisi di lapangan sebenarnya guna mendukung tujuan pelaksanaan kegiatan.

Tahap evaluasi merupakan bagian akhir sebelum penarikan kesimpulan. Evaluasi dilakukan untuk menilai dan mengetahui sejauh mana kegiatan dapat bermanfaat. Sehingga dapat digunakan sebagai pedoman untuk pelaksanaan kegiatan sejenis berikutnya. Apabila terdapat kekurangan bisa ditambahkan dan apabila terdapat kelebihan bisa diadopsi untuk kegiatan berikutnya.

Evaluasi dilakukan dengan cara mewajibkan peserta yang telah mengikuti kegiatan untuk mengisi kuesioner dengan pertanyaan yang sama seperti sebelum workshop dilakukan, serta mengisi satu lagi kuesioner tentang pelaksanaan kegiatan yang telah dilaksanakan. Tujuan dari evaluasi ini yaitu untuk mengetahui sejauh mana kegiatan yang dilaksanakan ini berjalan, apakah 
sudah cukup atau perlu perbaikan. Sehingga dapat digunakan sebagai referensi apabila mengadakan kegiatan sejenis tidak terulang kesalahan yang sama. Adapun kuesioner akhir yang diisi peserta terlihat di tabel 2 .

Tabel 2. Kuesioner akhir kegiatan

\begin{tabular}{cl}
\hline No. & \multicolumn{1}{c}{ Pertanyaan } \\
\hline 1. & $\begin{array}{l}\text { Kegiatan ini bermanfaat sekali bagi saya } \\
\text { pribadi maupun institusi tempat saya } \\
\text { bekerja }\end{array}$ \\
2. & $\begin{array}{l}\text { Saya senang apabila kegiatan seperti ini } \\
\text { dilakukan lagi di masa mendatang. }\end{array}$ \\
3. & $\begin{array}{l}\text { Secara umum saya puas dengan kegiatan } \\
\text { yang telah dilaksanakan ini. }\end{array}$ \\
\hline
\end{tabular}

Hasil kuesioner sebelum dan sesudah kegiatan diolah dan disajikan dalam bentuk grafik sehingga mudah dipahami. Selain itu, hasil kuesioner tentang pelaksanaan kegiatan juga disajikan dalam bentuk grafik yang dilengkapi dengan uraian secara deskriptif. Dengan demikian, kesimpulan yang dibuat menjadi lebih mudah disampaikan guna memberikan rekomendasi pelaksanaan berikutnya.

\section{HASIL DAN PEMBAHASAN}

\section{Proses Kegiatan Pembelajaran}

Sesuai dengan desain kegiatan yang sudah dirancang dalam dua tahap, kegiatan workshop sendiri dilakukan dalam dua hari di pekan yang berbeda yaitu hari pertama dilaksanakan pada Sabtu, 2 Februari 2019, dan hari kedua di pekan kedua yaitu Jumat, 8 Februari 2019. Tempat pelaksanaan dipusatkan di laboratorium komputer SMK Muhammadiyah 8 Tanon, Sragen dengan spesifikasi komputer yang sudah terhubung internet dan sudah mendukung untuk melaksanakan proses kegiatan workshop. Pemilihan tempat ini didasari pada ketersediaan sarana prasaran pendukung dan kesiapan sekolah sebagai tempat kegiatan. Peserta yang terlibat dalam kegiatan ini sebanyak 14 orang guru perwakilan dari beberapa sekolah Muhammadiyah di kecamatan Tanon, kabupaten Sragen. Informasi sebaran peserta dan asal sekolah bisa dilihat pada tabel 3.
Tabel 3. Sebaran asal sekolah peserta

\begin{tabular}{clc}
\hline No. & \multicolumn{1}{c}{ Nama Sekolah } & Jml \\
\hline 1. & SMK Muhammadiyah 8 Tanon & 5 \\
2. & SMP Muhammadiyah 5 Tanon & 1 \\
3. & SD Birrul Walidain Muhammadiyah & 1 \\
4. & MIS Muhammadiyah Slogo & 1 \\
5. & TK ABA Slogo & 2 \\
6. & TK Aisyiyah BA Suwatu & 1 \\
7. & TK Kreatif Aisyiyah Bustanul Athfal & \\
& Jono & 1 \\
8. & TK Pertiwi Kecik 1 & 1 \\
9. & TK Aisyiyah Pengkol & 1 \\
\hline & \multicolumn{2}{c}{ Jumlah total } \\
\hline
\end{tabular}

Seluruh nama sekolah yang tertulis pada tabel 3 berada di area kecamatan Tanon kabupaten Sragen. Jumlah peserta terbanyak berasal dari SMK Muhammadiyah 8 Tanon yaitu 5 orang, disusul TK ABA Slogo dengan jumlah sebanyak 2 orang. Hal ini terjadi karena tuan rumah tempat kegiatan berada di SMK Muhammadiyah 8 Tanon. Selain itu peluang terbesar untuk menerapkan ilmu pasca kegiatan berada di SMKini, sehingga tingkatkebutuhannya dibanding sekolah lain yang menjadikan jumlah keterlibatan peserta juga besar.

Sebelum kegiatan workshop ini dilaksanakan, kuesioner dibagikan kepada peserta dengan cara menunjukkan link kuesioner di layar. Hasil kuesioner yang diisi oleh peserta sebelum dilaksanakan workshop disajikan pada tabel 4. Sebanyak 14 peserta mengisi kuesioner berdasarkan pertanyaan yang tersaji pada tabel 1 dengan rentang skor jawaban 1-5. Terlihat bahwa tidak ada satu pun responden yang menjawab dengan nilai 5. Nilai tertinggi hanya 3 , yaitu pada pertanyaan pertama sebanyak 3 orang dan pertanyaan kedua sebanyak 3 orang serta pada pertanyaan 3 dan empat hanya 1 orang. Hal ini berarti bahwa pengetahuan peserta tentang cloud computing Google Drive dan aplikasinya masih minim. Artinya, sebagian besar peserta masih belum mengetahui manfaat dan cara penggunaan aplikasi berbasis cloud Google Drive. Selain itu, para peserta juga belum mengetahui jenis-jenis aplikasi cloud computing termasuk Google Drive. 
Tabel 4. Respon peserta sebelum workshop

\begin{tabular}{ccccc}
\hline \multirow{2}{*}{$\begin{array}{c}\text { Responden } \\
\text { (R) }\end{array}$} & \multicolumn{4}{c}{ Pertanyaan kuesioner } \\
\cline { 2 - 5 } R1 & 3 & 3 & 2 & 2 \\
R2 & 3 & 3 & 2 & 2 \\
R3 & 2 & 2 & 2 & 2 \\
R4 & 2 & 2 & 2 & 1 \\
R5 & 2 & 1 & 1 & 1 \\
R6 & 1 & 1 & 1 & 1 \\
R7 & 3 & 3 & 3 & 3 \\
R8 & 2 & 2 & 1 & 2 \\
R9 & 1 & 1 & 1 & 1 \\
R10 & 2 & 2 & 1 & 2 \\
R11 & 1 & 1 & 1 & 1 \\
R12 & 2 & 2 & 2 & 2 \\
R13 & 2 & 1 & 1 & 1 \\
R14 & 1 & 1 & 1 & 1 \\
\hline
\end{tabular}

Proses penyampaian materi workshop dilakukan dengan metode pembelajaran aktif (active learning) yang memungkinkan kegiatan menjadi lebih aktif. Pemilihan metode ini dilakukan agar para peserta berani mengungkapkan pikiran, keinginan, dan halhal lain yang mungkin tidak diketahui sehingga menjadikan suasana kegiatan menjadi lebih menarik. Selain itu juga menjadikan peserta lebih aktif berpartisipasi sehingga menjadikan Pemateri lebih mudah mengarahkan dan membimbing materi tentang aplikasi berbasis cloud computing Google Drive ini.

Proses penyampaian materi diawali dengan gambaran umum tentang teknologi cloud computing sehingga wawasan peserta menjadi lebih terbuka. Selanjutnya, cara kerja dan jenis layanan cloud computing disampaikan ke peserta agar mengetahui proses kerja dan layananlayanan yang terdapat pada teknologi. Secara lebih lengkap, jenis-jenis aplikasi berbasis cloud yang terdapat di Google Drive juga disampaikan secara garis besar dan kegunaannya masingmasing, misalnya Google Docs digunakan untuk mengolah kata, Google Sheets untuk mengolah formula atau data, dan Google Forms untuk membuat dan mendistribusikan kuesioner. Materi tentang Google Forms inilah yang dibahas secara lebih mendalam sehingga peserta dapat membuat, menyebarkan, dan mengolah kuesioner secara lebih efektif dibanding menggunakan metode penyebaran kuesioner konvensional.

Tahap demi tahap secara teknis tentang Google Forms dibahas dan disampaiak kepada peserta, selanjutnya peserta mengikuti instruksi yang disampaikan oleh pemateri, mulai dari tahap membuka link utama https://drive.google. com, login menggunakan akun Gmail masingmasing, dan memilih aplikasi Google Form. Selanjutnya, peserta dituntun dan diarahkan untuk membuat sebuah pertanyaan survei atau kuesioner melalui tombol menu yang tersedia di aplikasi. Selanjutnya diberikan penjelasan tentang pilihan jawaban yang bisa dilakukan oleh calon pengisi kuesioner, misalnya jawaban pendek (short answer), paragraf, pilihan ganda (multiple choice), checkbox, drowpdown, unggah berkas (file upload), skala liner, hingga jenis jawaban tentang tanggal dan waktu. Pilihan jawaban ini dijelaskan satu persatu sehingga peserta memahami fungsi dan kegunaannya ketika akan membuat kuesioner sesuai dengan yang dibutuhkan. Gambar 3 merupakan salah satu suasana kegiatan ketika peserta memperhatikan layar komputer di hadapan mereka sambil sesekali memperhatikan display yang tampil di layar lebar.

Karena menggunakan metode pembelajaran aktif, peserta diperkenankan untuk langsung bertanya tentang kesulitan dan kendala yang dihadapi saat penyampaian materi berlangsung. Peserta juga diberikan kesempatan untuk praktik mencoba secara langsung setelah Pemateri memberikan instruksi. Untuk memastikan bahwa peserta memahami dan mengerti tentang yang disampaikan, sesekali Pemateri berkeliling dan mendekati peserta yang sedang mempraktikkan instruksi dari Pemateri. Sehingga peserta tidak ketinggalan materi. Pemateri kadang juga diundang untuk mendekat ke peserta guna memberikan penjelasan lebih detail. Umpan balik antara peserta dan pemateri inilah yang menjadi kekuatan dalam menyampaikan materi tentang tata cara pengelolaan kuesioner secara daring menggunakan aplikasi cloud computing Google Drive. Gambar 4 merupakan salah satu aktivitas pemateri mendatangi tempat duduk peserta untuk memberikan penjelasan lebih detail.

Warta LPM, Vol. 22, No. 2, September 2019 


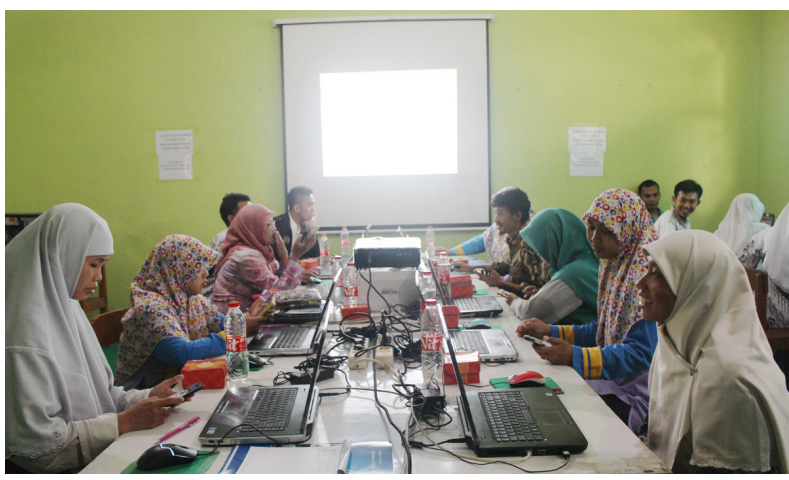

Gambar 3. Peserta mengikuti instruksi Pemateri

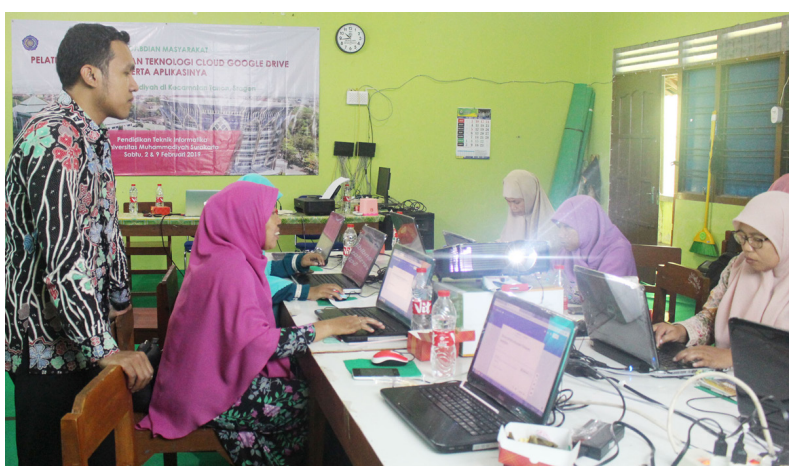

Gambar 4. Pemateri mendatangi peserta

Setiap selesai dalam satu sub-bab, pemateri selalu melakukan konfirmasi ke peserta apakah masih ada hal yang belum diketahui atau tidak, jika sudah tidak ada yang ditanyakan atau dibahas maka dilanjutkan dengan sub materi berikutnya. Konfirmasi ini perlu dilakukan karena tidak semua peserta memiliki kemampuan yang sama dalam menangkap materi yang disampaikan. Hal ini disadari karena peserta yang heterogen dan berasal dari berbagai sekolah dengan perbedaan latar belakang pendidikan dan aktivitas yang dilakukan. Dengan demikian, tujuan kegiatan pengabdian masyarakat berupa pelatihan ini dapat berjalan sesuai dengan tujuan untuk mengatasi permasalahan yang terjadi pada guru di lingkungan sekolah Muhammadiyah di kecamatan Tanon.

\section{Monitoring dan Evaluasi Kegiatan}

Setelah kegiatan berlangsung, peserta diwajibkan mengisi kuesioner sama seperti dengan pertanyaan sebelum mengikuti workshop, yaitu seperti yang disajikan pada tabel 1. Hanya saja, pertanyaan kedua bisa sedikit diabaikan karena menanyakan kebiasaan penggunaan Google Drive. Pertanyaan ini sedikit kurang relevan karena peserta baru mengenal aplikasi Google Drive paling lama satu minggu sejak pelatihan pertama di pekan sebelumnya. Adapun kuesioner atas pertanyaan yang diisi peserta pasca kegiatan tersaji pada tabel 5.

Tabel 5. Respon peserta pasca kegiatan

\begin{tabular}{ccccc}
\hline \multirow{2}{*}{$\begin{array}{c}\text { Responden } \\
\text { (R) }\end{array}$} & \multicolumn{4}{c}{ Pertanyaan kuesioner } \\
\cline { 2 - 5 } R1 & 5 & 5 & 4 & 5 \\
R2 & 5 & 5 & 4 & 4 \\
R3 & 4 & 4 & 5 & 4 \\
R4 & 4 & 3 & 4 & 4 \\
R5 & 4 & 4 & 4 & 4 \\
R6 & 4 & 3 & 4 & 5 \\
R7 & 5 & 5 & 5 & 3 \\
R8 & 4 & 4 & 4 & 4 \\
R9 & 4 & 2 & 3 & 3 \\
R10 & 4 & 4 & 3 & 4 \\
R11 & 3 & 3 & 5 & 3 \\
R12 & 4 & 4 & 4 & 2 \\
R13 & 4 & 2 & 4 & 4 \\
R14 & 3 & 2 & 4 & 4 \\
\hline
\end{tabular}

Perbandingan hasil tanggapan peserta antara sebelum dan sesudah kegiatan yang diolah dalam persentase tersaji dalam bentuk diagram batang gambar 3. Diperoleh nilai sebesar 38,57\% sebelum mengikuti kegiatan dan sesudah mengikuti kegiatan naik menjadi 81,43\% melalui pertanyaan pertama tentang pengetahuan peserta terkait aplikasi cloud computing Google Drive.

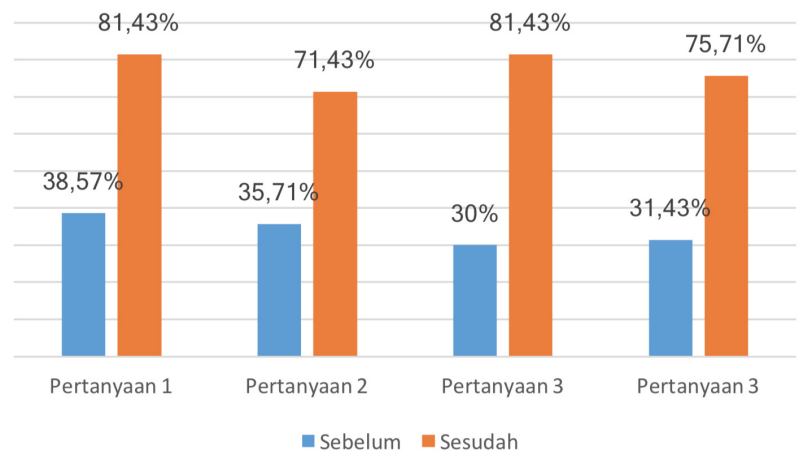

Gambar 3. Tanggapan peserta sebelum dan sesudah kegiatan 
Jika dianalisis dari pertanyaan pertama, terdapat dua istilah yang bisa dianggap asing oleh peserta, yaitu "cloud computing" dan "Google Drive". Saat ditanyakan tentang "cloud computing" waktu kegiatan dilaksanakan, tidak ada peserta yang mengetahui tentang istilah tersebut. Tetapi ketika ditanyakan tentang Google Drive, sebagian kecil menjawab bahwa mereka mengetahui. Namun seusai diberikan penjelasan lebih jauh tentang kedua istilah tersebut para peserta mulai memahami dan mengerti ternyata istilah yang digunakan itu sudah berada di sekitar mereka namun kurang menyadari dan kurang mengerti cara pemanfaatannya. Itulah sebabnya nilai tanggapan peserta setelah kegiatan mengalami kenaikan yang signifikan.

Pertanyaan kedua berkaitan dengan kebiasaan peserta dalam menggunakan aplikasi Google Drive. Hanya sekitar 35,71\% nilai tanggapan yang diperoleh dari peserta. Setelah kegiatan di hari pertama dan jeda selama satu minggu, tanggapan peserta berubah menjadi sebesar 71,43\%. Artinya bahwa peserta mulai menerapkan ilmu yang didapatkan di kegiatan dalam aktivitas kehidupan sehari-hari. Meskipun dalam jeda waktu seminggu tersebut belum bisa digunakan sebagai generalisasi, tetapi setidaknya memberikan informasi bahwa peserta mulai memanfaatkan teknologi yang sebenarnya sudah berada di sekitar mereka.

Sedangkan untuk pertanyaan ketiga dan keempat berkaitan dengan jenis-jenis aplikasi Google Drive dan cara penggunaannya. Tanggapan sebelum kegiatan masing-masing sebesar 30\% dan 31,43\%, naik menjadi $81,43 \%$ dan $75,71 \%$ setelah kegiatan berlangsung. Hal ini berarti bahwa kegiatan yang dilaksanakan ini memberikan dampak positif terhadap peserta terkait pemanfaatan aplikasi cloud computing Google Drive untuk kegiatan sehari-hari. Peserta menjadi tahu beberapa jenis aplikasi berbasis cloud dari Google Drive dan cara penggunaannya. Dengan demikian, diharapkan ilmu pengetahuan yang sudah diperoleh para peserta dapat diterapkan dan dimanfaatkan untuk mendukung efektivitas kinerja seharihari untuk keperluan akademis maupun nonakademis sekolah.
Tabel 6.Tanggapan peserta terhadap kegiatan

\begin{tabular}{cccc}
\hline \multirow{2}{*}{ Responden } & \multicolumn{3}{c}{ Pertanyaan } \\
\cline { 2 - 4 } & Q1 & Q2 & Q3 \\
\hline R1 & 4 & 4 & 4 \\
R2 & 4 & 5 & 5 \\
R3 & 5 & 5 & 5 \\
R4 & 5 & 5 & 5 \\
R5 & 4 & 5 & 4 \\
R6 & 5 & 5 & 5 \\
R7 & 5 & 5 & 5 \\
R8 & 4 & 5 & 4 \\
R9 & 5 & 4 & 5 \\
R10 & 5 & 5 & 4 \\
R11 & 5 & 5 & 5 \\
R12 & 4 & 4 & 4 \\
R13 & 5 & 5 & 4 \\
R14 & 4 & 5 & 5 \\
\hline Presentase nilai & $91,43 \%$ & $95,71 \%$ & $91,43 \%$ \\
\hline
\end{tabular}

Sebelum kegiatan berakhir, peserta diminta untuk mengisi kuesioner yang berkaitan dengan pelaksanaan kegiatan secara umum melalui pertanyaan yang tersaji di tabel 2. Pertanyaan ini dibuat dan disampaikan ke peserta sebagai bentuk evaluasi tentang kegiatan yang telah berlangsung. Sehingga diperoleh umpan balik dari peserta yang dapat digunakan sebagai landasan untuk mengadakan kegiatan sejenis di masa yang akan datang. Tanggapan peserta terhadap kuesioner tingkat kepuasan kegiatan tersaji pada tabel 6 .

Sebesar 91,43\% tanggapan diperoleh dari survei yang dilakukan terhadap 14 peserta kegiatan dengan pertanyaan terkait seberapa besar manfaat dari kegiatan yang diikuti oleh mereka. Sementara, pertanyaan berkaitan dengan tanggapan mereka apabila kegiatan sejenis dilaksanakan lagi di masa mendatang diperoleh nilai sebesar 95,71\%. Dan pertanyaan yang berkaitan dengan tingkat kepuasan peserta terhadap kegiatan yang dilaksanakan secara umum memperoleh nilai sebesar 91,43\%. Dengan demikian dapat dikatakan bahwa kegiatan yang dilaksanakan ini bermanfaat dan berharap ada kegiatan lanjutan sejenis untuk meningkatkan kemampuan para guru di 
bidang teknologi informasi. Karena berdasarkan wawancara singkat kepada peserta, mereka jarang sekali memperoleh pelatihan sejenis di daerahnya. Sehingga, kegiatan seperti ini dapat ditindaklanjuti untuk kegiatan-kegiatan berikutnya di masa yang akan datang, khususnya para guru Muhammadiyah di kecamatan Tanon, Sragen.

\section{KESIMPULAN}

Dari uraian pembahasan di atas diperoleh kesimpulan bahwa kegiatan pelatihan penggunaan aplikasi berbasis cloud computing sejenis Google Drive yang sudah dilaksanakan ini bermanfaat bagi peserta yang merupakan para guru Muhammadiyah di area kecamatan Tanon, Sragen. Hal ini diperoleh dari hasil survei terhadap seluruh peserta sebanyak 14 orang yang nilanya sebesar 91,43\%. Dari segi pengetahuan, persentase tanggapan peserta juga meningkat dari sebelum kegiatan dan sesudah kegiatan yang dibuktikan dari hasil pengisian kuesioner. Respon peserta melalui kuesioner juga menyatakan bahwa mereka tertarik untuk mengikuti pelatihan seperti ini untuk menambah wawasan tentang teknologi informasi dan pemanfaatannya.

\section{PERSANTUNAN}

Ucapan terima kasih kasmi sampaikan kepada Lembaga Penelitian dan Pengabdian kepada Masyarakat (LPPM) UMS yang telah membantu pendanaan sehingga kegiatan dapat berjalan dengan baik. Selain itu, terima kasih juga kami sampaikan kepada SMK Muhammadiyah 8 Tanon dan sekolah Muhammadiyah di Tanon yang turut serta membantu dan berpartisipasi sehingga kegiatan dapat berjalan dengan lancar.

\section{DAFTAR PUSTAKA}

Euis, E., \& Heryana, N. (2018). Analisis Pemanfaatan Cloud Computing Berbasis Software as a Service sebagai Media Penyimpanan Tugas Praktikum. Syntax: Jurnal Informatika, 7(1), 26-32.

Fardani, A., \& Surendro, K. (2011). Strategi adopsi teknologi informasi berbasis cloud computing untuk usaha kecil dan menengah di Indonesia. In Seminar Nasional Aplikasi Teknologi Informasi (SNATI).

Google. (2018). Google Drive - Cloud Storage \& File Backup for Photos, Docs \& More. Retrieved August 28, 2018, from https://www.google.com/drive/

Handayani, I., Kusumahati, H., \& Badriah, A. N. (2017). Pemanfaatan Google Spreadsheet Sebagai Media Pembuatan Dashboard pada Official Site iFacility di Perguruan Tinggi. Sisfotenika, 7(2), 177-186.

Iqbal, M., Rosramadhana, R., Amal, B. K., \& Rumapea, M. E. (2018). Penggunaan Google Forms Sebagai Media Pemberian Tugas Mata Kuliah Pengantar Ilmu Sosial. JUPIIS: JURNAL PENDIDIKAN ILMUILMU SOSIAL, 10(1), 120-127.

Kristin, F. (2017). Keberhasilan Belajar Mahasiswa Ditinjau Dari Keaktifan Dalam Perkuliahan Dengan Menggunakan Pembelajaran Active Learning. JURNAL PENDIDIKAN DASAR PERKHASA: Jurnal Penelitian Pendidikan Dasar, 3(2), 405-413.

Ningrum, O. S. (2015). Penggunaan Aplikasi Google Drive sebagai Penunjang Paperless Office. Jurnal Administrasi Perkantoran (JPAP), 3(3).

Syofian, S., Setiyaningsih, T., \& Syamsiah, N. (2015). Otomatisasi metode penelitian skala likert berbasis web. Prosiding Semnastek.

Warsito, A. B., \& Yuliandini, E. (2017). Penerapan Google Drive Untuk Efisiensi Penyimpanan Bahan Ajar Yang Dapat Mendukung Sistem Informasi Bahan Ajar Pada Perguruan Tinggi Berbasis Mobile Aplikasi. SISFOTENIKA, 7(2), 219-22 